\title{
絹鳴りの機構に関する研究
}

（第 1 報）繊維束交叉摩擦による絹鳴りの測定法について

$\begin{array}{ccccc}\text { 奈良女子大学家政学部 } & \text { 諸 } & \text { 岡 } & \text { 英 雄 (会員) } \\ & \text { " } & \text { 古 } & \text { 里 孝 吉 ( " } 1 \text { ) }\end{array}$

\section{Mechanism of Scrooping Sound of Silk}

\section{Part 1 : A Method for Scrooping Sound Measurement by Rubbing}

Two Fiber Bundles under Intersecting at Right Angles.

\author{
Hideo Morooka and Kokichi Furusato, \\ Department of Clothing Science, Nara Women's University, Nara.
}

\begin{abstract}
This study intends to investigate the mechanism of scrooping sound of silk. Part 1 describes a method to measure the scrooping sound of silk and describes the source of its measured sound. Further, an attempt has been made to clear the source of scrooping sound of silk.

The following results are obtained:

(1) A generating apparatus of frictional sound has been developed by rubbing two fiber bundles under intersecting at right angles just as violin strings, and an effective frictional sound has been generated.

(2) It is able to ignore the influence of the mechanical and outside noise.

(3) The measured sound is intermittent, and it is related to stick-slip vibration of friction.

(4) The intermittent vibration contains sounds of string transverse vibration and vibration sounds of about $8 \mathrm{KHz}$ frcquency whose source is now unknown.

(5) The scrooping sound of silk also contains an intermittent vibration which is almost about $8 \mathrm{KHz}$ in frequency.

(Received January 16, 1976)

\section{摘 要}

目 的 絹鳴りの機構を解明するととを目的とし本報では，絹鳴り測定の一方法とそれによる測定音の振動源につい て述べ，そして絹鳴りの振動を明らかにしょうとする。

成 果 1） 2本の䋞維束をバイオリン弦のような直交交叉摩擦による摩擦音発生器を試作し 摩擦音を発生させた。

2）本装置は，機㭜および外部騒音の影響を無視できた。

3）測定音は間欠振動で, 摩擦のスチックースリップ振動であることを明らかにした。

4）間欠振動には，弦の横振動に基因する振動音と，現在，振動源の不明な約 $8 \mathrm{KHz}$ の振動音が存在する.

5）絹鳴りにあ間欠振動があり，それには約 $8 \mathrm{KHz} の$ 振動音が最す多く存在する.
\end{abstract}

(昭和51年 1 月 16 日受理)

\section{1. 緒 言}

従来, 絹鳴りの測定方法に関する研究は少なく, 沢 路 ${ }^{12)}$ らによるスチックースリップ摩擦測定装置による 絹鳴りの良否判定方法があるが, Handling によって絹 鳴りを発生させているのが現状で, 直接, 音響振動を対 象とした客観的計測法はないと考える. その客観的計測 の実現を困難にしている理由としては，次の 2 つがあげ
られる。

(1) 絹鳴りは, 微弱音 (耳むとで, 約 $85 \sim 95 \mathrm{~dB}$ ) で あるため, 計測器に付随する機械騒音の防音対策がむず かしい.

(2) Handling 中の絹糸運動が捕えにくい. 以上のて とを考元，かつ“摩擦音”という観点に立ち，2 本の緘 維束を交叉摩擦する装置を試作し, 発生した摩擦音を究 
明することにより, 絹鳴りの発音機構を解明しょうとす るあのである.

\section{2. 装置}

\section{1 装置の概要}

図1 が装置の概要図で, 図 2 が試料の配置図, 図 3 が 実際の摩擦音発生器を表わす。装置は, 防音箱, 摩擦音 発生器, モ一夕回転制御器, 録音装置, 音響分析装置上 り構成されている.

摩擦音発生器は, 試料である 2 本の紻維束 $L_{1}, L_{2}$, 周用を綿瀻維で厚く巻いてモータ騒音を無視できるほど 小さくした卷取モータ $(W)$, 試料 $L_{2}$ の弦長を任意の長 さ代固定する弦長固定器 $J_{1}, J_{2}$, 交叉角度調整器 $(H)$ 滑らかな回転をし, かつ測定中騒音を出さない滑車 $G_{1}$, $G_{2}, G_{3}$ より成り立つ.

試料の配置は, 図 2 および四 3 のように, 試料 $L_{2}$ が 弦長固定器 $J_{1}, J_{2}$ 抢よび荷重 $T_{2}$ により弦長 $l$, 張力

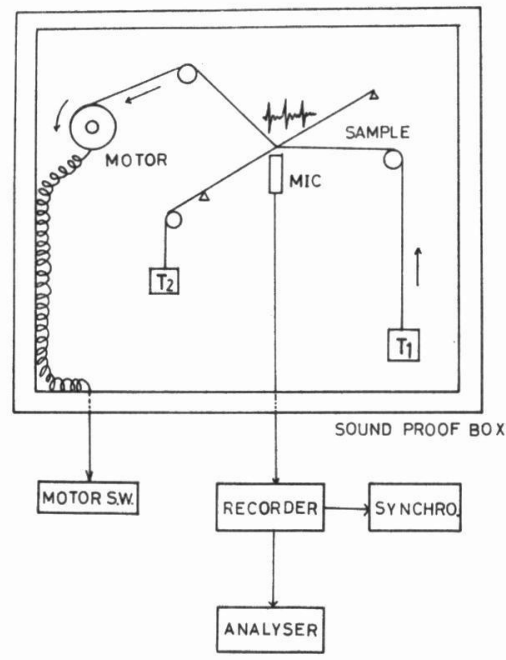

図1装活の概要図

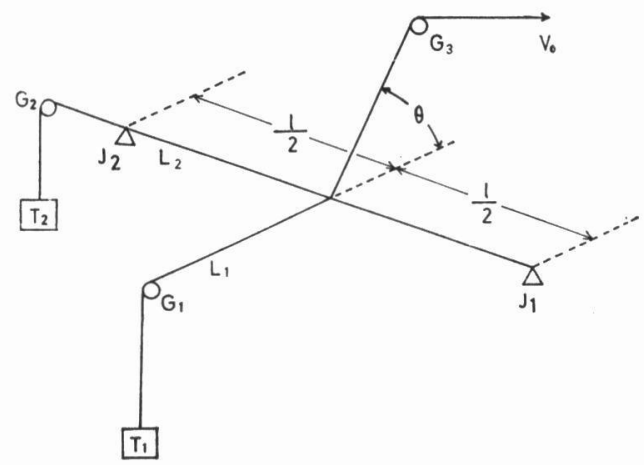

図 2 試料の配置

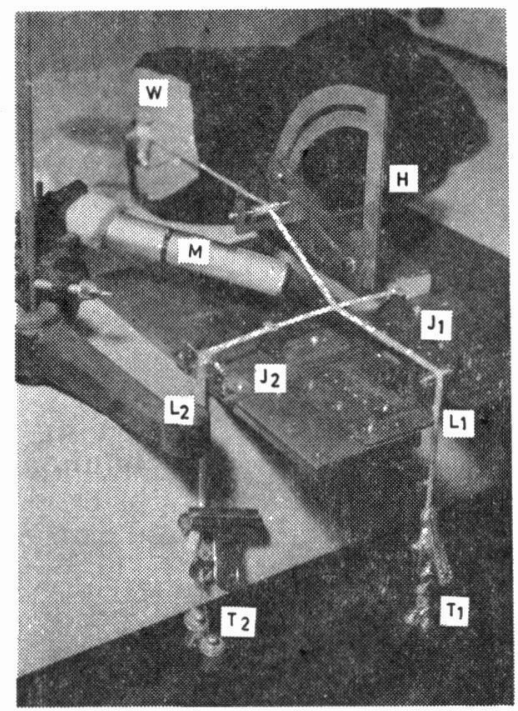
$L_{1}, L_{2}$ : 試料
$T_{1}, T_{2}:$ 荷雷
$H$ : 交叉角度調整器
$W:$ 卷取モ一夕
$J_{1}, J_{2}$ : 弦長調整器
$M:$ マイクロフォン

図 3 摩擦音発生器

$T_{2}$ で取り付けられる. 試料 $L_{1}$ は, その一端には, 荷 重 $T_{1}$ が吊るされ，他端は滑車 $G_{1}$ を通り， $L_{2}$ とその $l / 2$ の位置で直交しかつ, 下侧を通り, 交叉角 $\theta$ で滑車 $G_{3}$ に至り巻取モータの巻取口に付いている. 巻取モ一 夕は, 防音箱外よりモータ回転制御器で操作可能で, 試 料 $L_{1}$ を一定速度 $V_{0}$ で巻きあげる. この時, 試料 $L_{1}$ と $L_{2}$ の交叉部分から摩擦音が発生する。 それをマイク口 フォンで検出し,いったん, テープレコーダに録音した 後, 分析を行う。

防音箱は, その大きさが縦 $1 \mathrm{~m} \times$ 横 $1 \mathrm{~m} \times$ 奥行 $1 \mathrm{~m}$ で, 内部には厚さ約 $5 \mathrm{~cm}$ に綿繊維吸音材がきっちりとはら れ, 更にその内側に厚さ $5 \mathrm{~mm}$ の吸音板を張り, 更に厚 い毛布をはり防音効果を高めている.

また, 滑車 $G_{1}, G_{2}, G_{3}$ はその中央に幅 $1 \mathrm{~mm}$, 深さ $1 \mathrm{~mm}$ 溝があり, 試料 $L_{1}$ の横すべりを防いでいる.

\section{2 録音招よび分析装置}

録音に使用したマイクロフォンは SONY-ECM22P で 有効周波数は, $16 \mathrm{~Hz} \sim 20 \mathrm{KHz}$, 録音器は, $\mathrm{TEAC}$ 社の $\mathrm{A}-2300 \mathrm{~S}$ (有効周波数 $30 \mathrm{~Hz} \sim 22 \mathrm{KHz}$ ) を用い, それ らを組合せた場合の周波数特性を図 4 亿示す。これより 我々人間が感じる絹鳴りの検出, 測定には適当であると とがわかる。

音響分析装置は， $\mathrm{B} \& \mathrm{~K}$ 社のへテロダイン方式の周波 数分析により周波数分析を試みたが，減衰の速い間欠的 


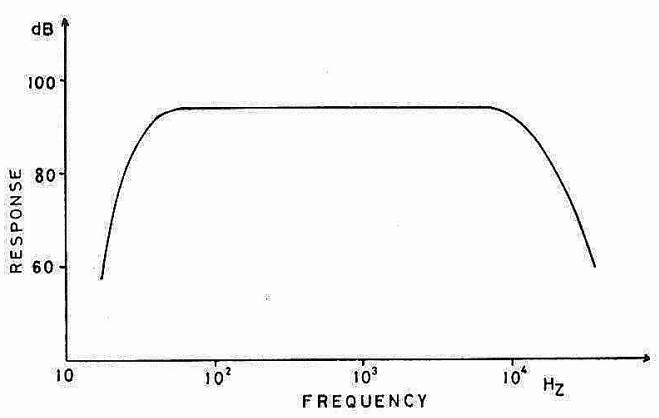

图 4 録音装㯰 (マイクとレコーダ) の周波数特性

音響振動に対しては有効ではなかったのでいっったん， $\mathrm{TEAC}$ 社のデータレコーダ (位相平坦特性 $\mathrm{DC} \sim 20 \mathrm{KHz}$ ) に録音し直し，再生速度を録音速度の $1 / 20$ 亿低下させ て，横河電機社製，電磁オシログラフ（位相 平坦特性 $\mathrm{DC} \sim 1 \mathrm{KHz})$ に上り波形を記録し，元れ上り周诐数を測 定した。なお，音生測定には， $\mathrm{B} \& \mathrm{~K}$ 社の騒音計 2608 型 を使用した。

\section{3. 試料および実験条件}

\section{1 試 料}

試料は，1973年春，山梨産，春嶺 $\times$ 鐘月，21d の生系 を使用し，下記の方法て精練を行った．石けんによる精 練を行い絹系重量の 50 倍量の $0.5 \%$ 石けん水溶液で 30 $\min$ 間, $95 \sim 97^{\circ} \mathrm{C}$ で処理し, 臬依液を新しく変えて, 同様の $30 \mathrm{~min}$ 間处理堂行い, 水洗後, $1 \%$ 炭酸りーダ水溶 液に $10 \mathrm{~min}$ 間浸漬し, 更に $1 \%$ の酸水溶液に浸漬し, 後, 風乾し供用試料とした。酸は酒石酸 $\mathrm{C}_{2} \mathrm{H}_{2}(\mathrm{OH})_{2}$ $(\mathrm{COOH})_{2}$ 杇よび乳酸 $\mathrm{CH}_{3} \mathrm{CH}(\mathrm{OH}) \mathrm{COOH}$ の 2 種類を用 やた. 練減率は $21.5 \%$ ，単系の断面積は，約 $0.558 \times$ $10^{-4} \mathrm{~mm}^{2}$ (日立明石製MINI SEM により測定)

比重は 1.345 (密度勾配管法により測定)

\section{2 実験条件}

モータの卷取速度 $V_{0}=140 \mathrm{~mm} / \mathrm{min}$, 交义角度 $\theta=$ $45^{\circ}$ ，録音テープ速度 $19 \mathrm{~cm} / \mathrm{sec}$ を用いた。試料 $L_{1}$ の本 数は200本で, 試料 $L_{2}$ は, 190 本, 300本, 1200 本の 3 種について測定した。 $L_{2}$ の弦長拈よび荷重については 種々変化させて夷験した。測定は， $20^{\circ} \mathrm{C}, 65 \% \mathrm{RH}$ の 恒温恒湿室中で行った。

\section{4. 結果および考察}

\section{1 波形飞ついて}

測定された摩擦音の波形は图 5 のような間欠振動であ った、とれをA振動とする。また，ての波形の時間軸を㹡 大すると，図 6 のBおよび振動加顕著に見られた。図 7 は2 $500 \mathrm{~Hz}$ に，遮断周波数老持つハ1パス フィ

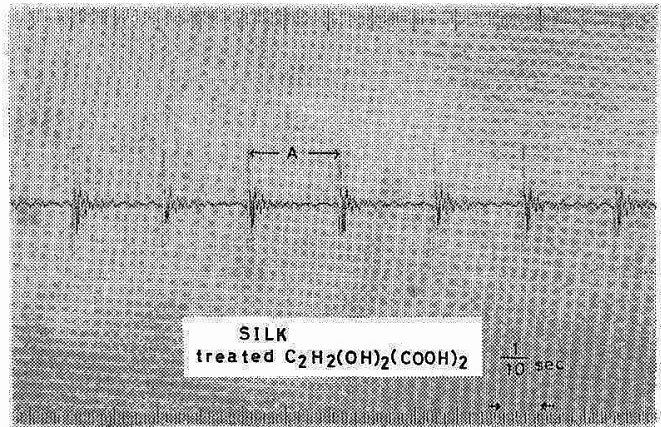

図 5 測定音の波形（A振動）

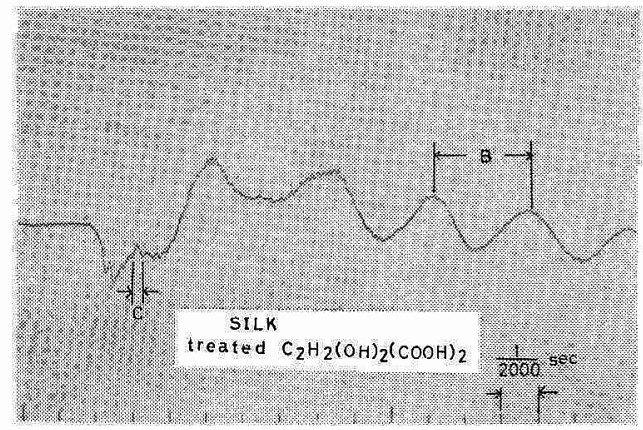

図 6 時間朝を㧨大した湘定音の波形 ( B, C 振動)

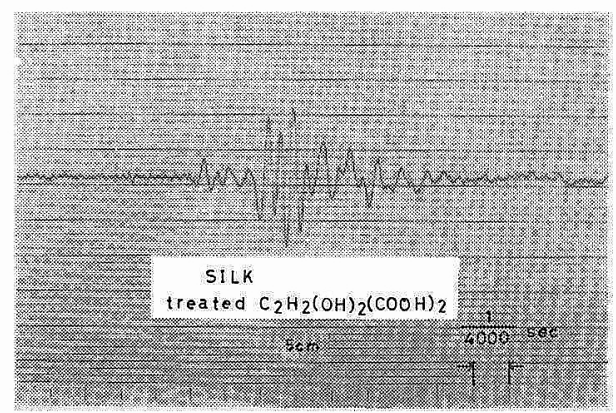

园7ハィパスフィルタを通した後の 測定音の波形（C振動）

ルタを用けて，C振動成分を記録したものである．以上 のような 3 つの振動が顕著に見られた。. 次いで，A，B Cの各々について, 专の振動源を究明するための実験を 行った.

\subsection{A振動について}

本測定器は, バイオリンの弦振動発生機構と同様と考 えられるので, A振動は, Helmholtz ${ }^{3}$ ) の振動論のステ ックースリップ振動に相当するのではないかと考え，巻 取もータの代わりに，図８のようなU一ゲージを乗せた 水平引張器を用いて, 摩擦を測定したところ, 図 9 のよ うなスチックースリップ現象が測定され, それの振動数 


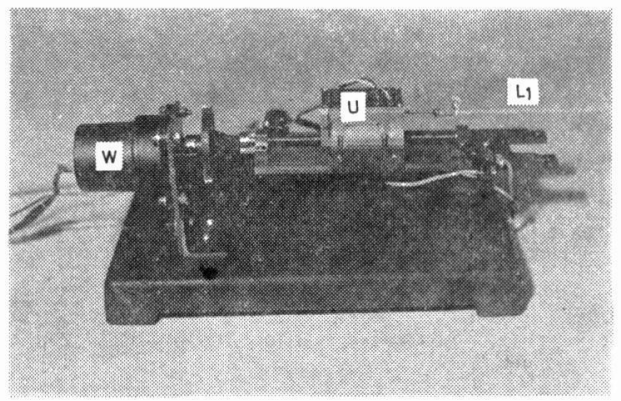

W : モータ U : U-ゲージ, $L_{1}$ : 武料

図 8 水平引張器 (摩擦測定器)

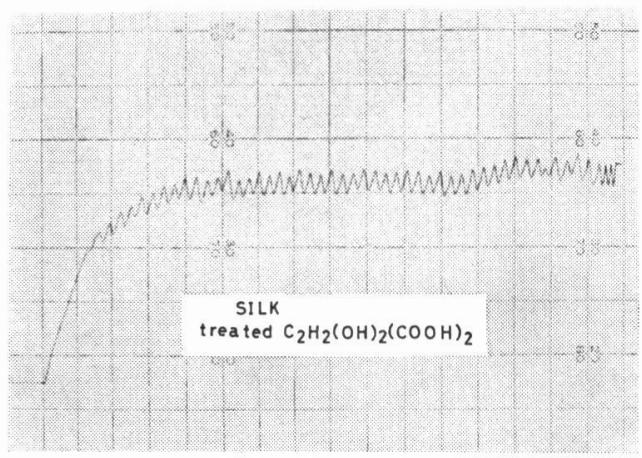

図 9 摩擦の記録図

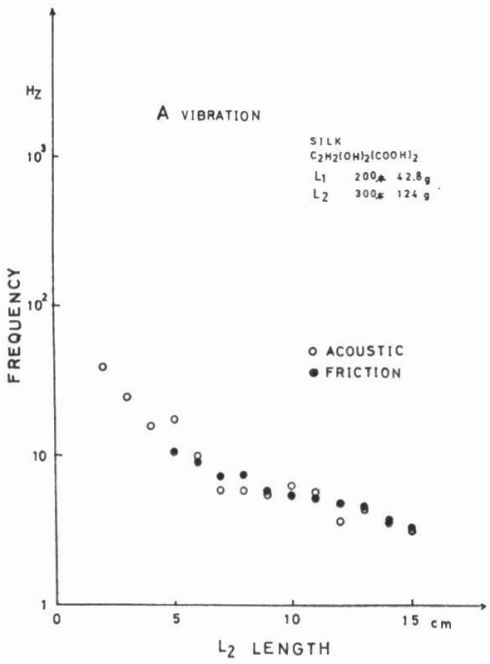

図10 A 振動とスチックースリップ振動の比較

とA振動数とを比較検討した. 図10は, 酒石酸処理をし た練絹を用いて，試料 $L_{2}$ の弦長とその振動数との関係 を音響測定結果（○印）上，摩擦測定結果 上）上考

比較した図で, 両者はよく一致した.ただし,摩擦測定に おいて, 試料 $L_{2}$ の弦長が $5 \mathrm{~cm}$ 以下の場合は，記録計 のペン速度の関係で測定できなかった，その測定条件は
試料 $L_{1}$ の本数 200 本, 荷重 $T_{1}=42.8 \mathrm{~g}$, 巻取速度 $V_{0}=$ $140 \mathrm{~mm} / \mathrm{min}$ である.

以上より，A振動は，“間欠である”という点と，“摩 擦のスチックースリップ振動数との一致” から，スチッ クースリップ振動であることがわかった。

\subsection{B振動について}

上述のように, 本装置は, バイオリンの弦振動発生機 構と同様と考えられるから, 弦の横振動の発生が最も起 こりやすいと考えられる. 一般に, 弦の横振動数は次式 で表わされる.

$$
f=\frac{n}{2 l} \sqrt{\frac{T}{\rho}}
$$

$$
\begin{array}{ll}
f: \text { 振動数 }(\mathrm{Hz}), \quad l: \text { 弦長 }(\mathrm{cm}) \\
T: \text { 張力 }(\mathrm{dyn}) & \rho: \text { 線密度 }(\mathrm{g} / \mathrm{cm}) \\
n: 1,2,3 \cdots \cdots &
\end{array}
$$

$n$ は, 弦の幾何学的形状によって決定されるのであるが 本装置の場合，弦中央に交叉圧が加わっているため，そ れにより弦の幾何学的形状は, 複雑に変化すると思われ るが, 拈扔よそ, $n=3$ に近い振動数の発生がある上考 えられる。

図11は, 酒石酸処理試料を, 試料 $L_{1}$ の本数 200 本, 荷重 $T_{1}=42.8 \mathrm{~g}$, 試料 $L_{2}$ の本数 1200 本, 荷重 $T_{2}=$ $124 \mathrm{~g}$, 交叉角度 $\theta=45^{\circ}$, 巻取速度 $V_{0}=140 \mathrm{~mm} / \mathrm{min}$ の 実験条件で, 試料 $L_{2}$ の弦長亡 B 振動数との関係を求め た結果である。○印は, 測定值で, 実線は, 横振動の理 論值でほぼ $n=3$ の振動数亡一致した。また。罒12は, 乳酸処理試料 $(\times$ 印) と酒石酸処理試料 (O印) の試料

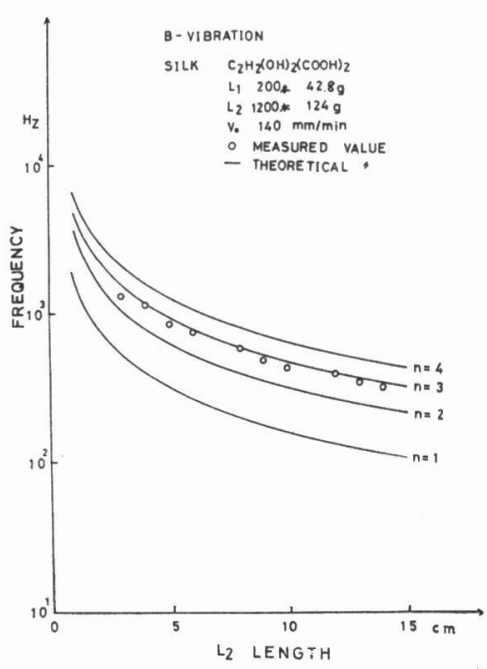

図11 $L_{2}$ の長さとB 振動数の関係 


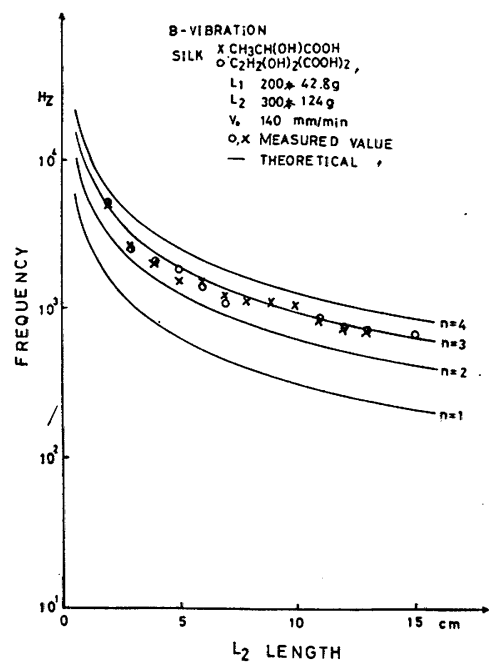

図12 $L_{2}$ の長さとB 振動数の関係

$L_{2}$ の弦長と $\mathrm{B}$ 振動数との 関 係を求めた 実 験結果であ る. 測定条件は両者とあまったく同一である. その結果 乳酸之酒石酸の酸処理による相異は見られず，まったく 同一結果が得られ， $n=3$ の理論值とほぼ一致した。

図11と12の結果をまとめると，

1）試料 $L_{2}$ の弦本数を変えても, 弦の横振動の理論 值の $n=3$ に近い振動数が得られた.

2）試料 $L_{2}$ の弦長を変化させると, 弦の横振動の理 論值 $n=3$ 亿近い振動数が得られた。

3）酸による違いは認められず, 同一結果が得られ た.

以上より, B 振動は, 弦の横振動に基因する振動音と 考えられる.

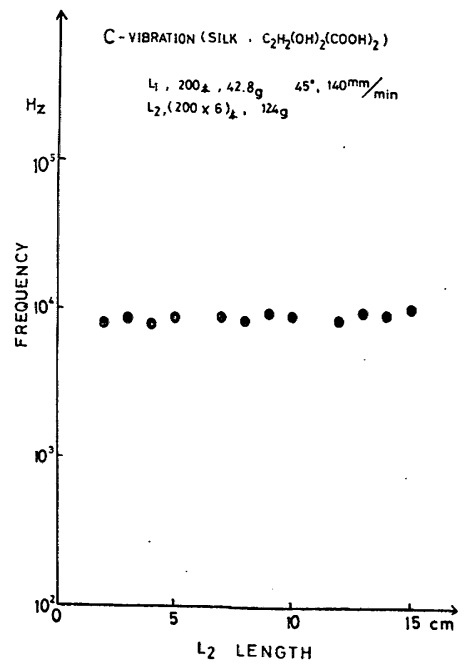

図13 $L_{2}$ の長さとC 振動数の関係

\subsection{C振動について \\ こてでは, ハイ パス フィルタを用いて, 測定音か} ら B 振動をカットし，C振動数を求めた. 図13は, 図11 の測定音のC振動に関する測定結果である。乙れより試 料 $L_{2}$ の弦長にほほ関係なく, 約 $8 \mathrm{KHz}$ の高域振動音が 得られた. また図14は, 試料 $L_{2}$ の荷重 $T_{2}$ を変化させ た場合の C 振動数の測定結果である. ての場合も, 約 8 $\mathrm{KHz}$ の高域振動音が張力に関 係なく得られた。なお, その測定条件は, 試料 $L_{1}$ の本数 200 本, 荷重 $T_{1}=62.8 \mathrm{~g}$, 試料 $L_{2}$ の本数 190 本, 弦長 $l=10 \mathrm{~cm}$, 交叉角度 $\theta=$ $45^{\circ}$, 巻取速度 $V_{0}=140 \mathrm{~mm} / \mathrm{min}$ である.

以上, $\mathrm{C}$ 振動は, 弦長や, 張力に ほぼ無関係な約 8 $\mathrm{KHz}$ の高域振動音であった。乙の振動源については, 現在検討を進めている.

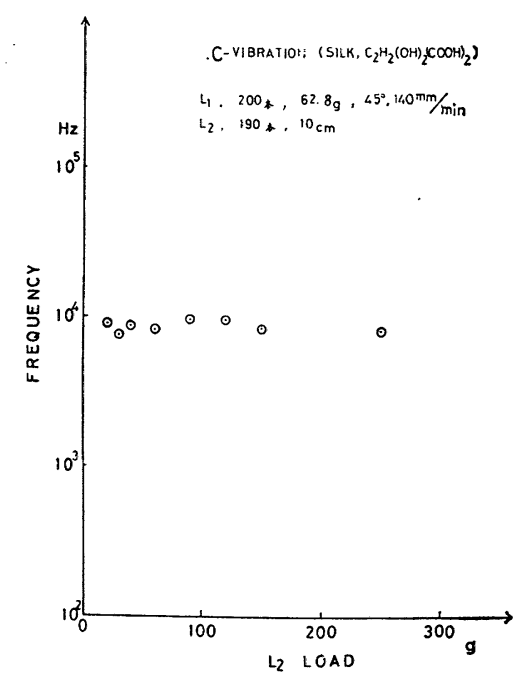

図14 $L_{2}$ の荷重と C 振動数の関係

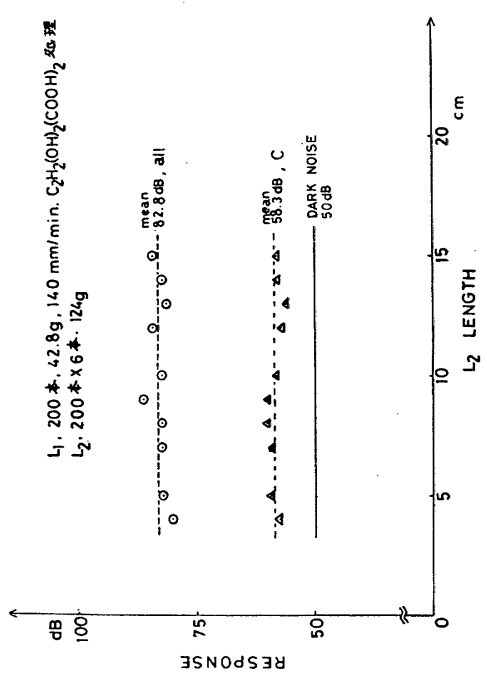

図15 $L_{2}$ の長さと音圧の関係 


\section{5 音圧について}

図15は, 四11 の測定音の試料 $L_{2}$ の弦長之音圧之の測 定結果であるが, 全音圧はほぼ $83 \mathrm{~dB}, \mathrm{C}$ 振動は, 約 $58 \mathrm{~dB}$ であった. 図120結果も同様の值であった。

また, 暗騒音は, 約 $50 \mathrm{~dB}$ で機械扔よで外部騒音の影 響は無視できた。

\subsection{Handling による絹鳴りとの関連}

図16は,酒石酸処理をした試料(約 $15 \mathrm{~g}$ )を Handling し たときの一握り全体の振動波形で間欠振動の発生がみら れる. その振動数分布が図 17 で, $50 \mathrm{~Hz} \sim 60 \mathrm{~Hz}$ の振動が

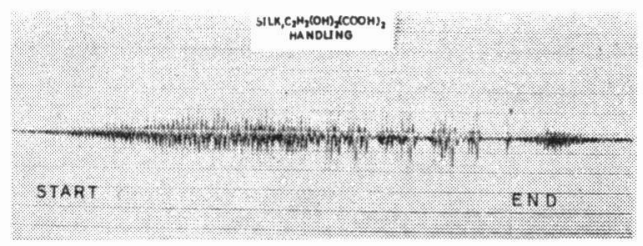

図16 絹鳴りの波形（一握り全体）

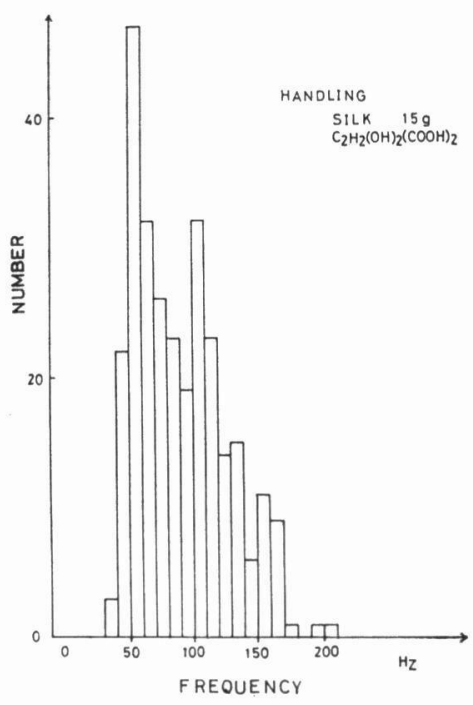

図17間欠振動の振動数分布

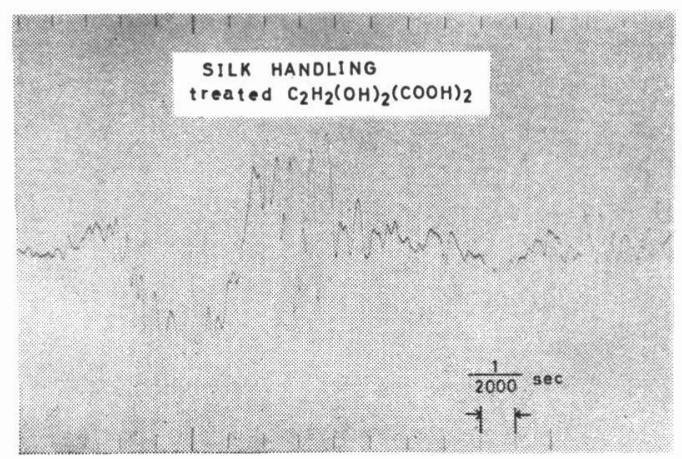

図18 絹鳴りの波形（1 個の間欠振動）

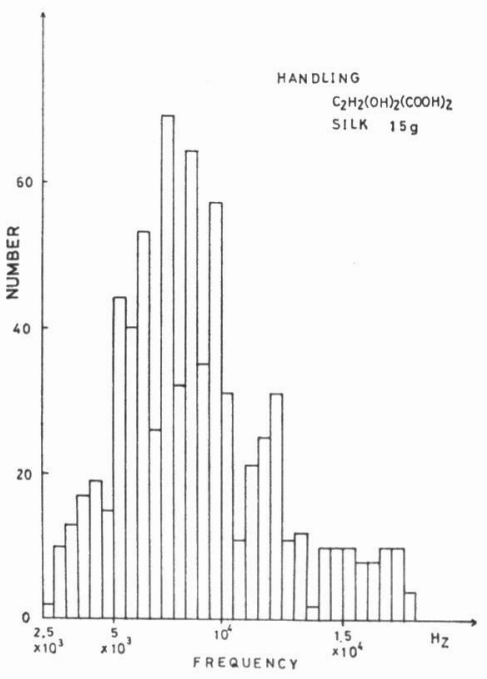

図19間欠振動に含まれる振動数分布

最む多く測定された．この間欠振動は, 本測定法の A 振 動に対応すると考えるととができ，したがって Handling 中に, 絹系相互間にスチックースリップ振動が発生して いると考えられる.

さらに，1個の間欠振動の波形の時間軸を拡大した波 形が図18で，それを構成している振動数分布を求めてみ ると図19の上うに, 約 $8 \mathrm{KHz}$ の高域振動音が最む多く 含まれていた．沢路氏4) お, 絹鳴りの波形から $7 \mathrm{KHz}$ 前 後の振動音を絹鳴りの特微音であろうとしているがやは り同様の結果を得たと考えられる. 弦長抒よび張力にほ ぼ関係なく, 約 $8 \mathrm{KHz}$ の振動音を発する $\mathrm{C}$ 振動が絹鳴 りの主たる振動ではないかと考元検討を進めている.

\section{5. 結 語}

以上のことから, 次の結果が得られた。

1）絹鳴りの客観的計測法として，2 本の瀻維束を交 议摩擦する摩擦音発生器を試作した。

2）その摩擦音には, 間欠振動がみられ, それは摩擦 測定結果と比較したところ，スチックースリップ振動で あることがわかった。

3）間欠振動の 1 個には, 弦の横振動音 ( $\mathrm{B}$ 振動) 上, 約 $8 \mathrm{KHz}$ のC 振動音が含まれていた.

4） C 振動は, 試料 $L_{2}$ の弦長, 張力を变えても, ほ ぼ $8 \mathrm{KHz}$ であった。こ机については現在検討中である.

5） Handling による絹鳴りにも間欠振動がみられ, 本測定法によるA振動と比較したところ, それはスチッ クースリップ振動上考えられる。

6) 絹鳴りの間欠振動の 1 個には, 種々の振動音が含 まれていたが, 約 $8 \mathrm{KHz}$ の振動音が多くみられた。 そ 
れが絹鳴りの特徵至と考えられるが，その振動源につい ては目下検討を進めている。

7）本測定器では，機械騒音を無視できた.

\section{6. あとがき}

本研究を進めるにあたって多大ので援助をいただいた 京都大学工学部佐藤進助教授, 中井幹雄講師, 博士課程の 横井雅之氏および実験に協力された奈良女子大四回生, 金山真知子, 塩見 早代子の両嬢に厚く感謝の意を表す る.
文献

1）沢路, 川口, 靿; 日本瀻維機械学会第20回年次大会 满演前刷 p.202 (1967)

2）沢路, 諸岡; 製系絹研究発㸞籍録, p.107（1970）

3) H. V. Helmholtz ; 「Die Lehre von dem Tonempfindungen」Brauschweig, 1973.

4）沢路; 絹鳴りとその計測, 繊維と工業, $31, p-317$ (1975) 